\title{
Rice Cultivation under Drip Irrigation with Plastic Film Mulch in the Kanto Area of Japan
}

\author{
Sangsoo Park ${ }^{1}$, Hiroki Nishikoji ${ }^{1}$, Shotaro Takahashi ${ }^{1}$, Oleasegun Olamide Fawibe ${ }^{1,2}$, \\ Peiwu Wang ${ }^{3}$, Akihiro Isoda ${ }^{1, *}$ \\ ${ }^{1}$ Graduate School of Horticulture, Chiba University, Matsudo, Chiba 271-8510, Japan \\ ${ }^{2}$ Department of Pure and Applied Botany, Federal University of Agriculture Abeokuta, PMB 2240, Alabata, Abeokuta, Nigeria \\ ${ }^{3}$ Xingjiang Tianyuan Institute of Rice Drip Irrigation System, Urumqi, Xinjiang, China
}

Received April 6, 2021; Revised June 22, 2021; Accepted July 19, 2021

\section{Cite This Paper in the following Citation Styles}

(a): [1] Sangsoo Park, Hiroki Nishikoji, Shotaro Takahashi, Oleasegun Olamide Fawibe, Peiwu Wang, Akihiro Isoda , "Rice Cultivation under Drip Irrigation with Plastic Film Mulch in the Kanto Area of Japan," Universal Journal of Agricultural Research, Vol. 9, No. 4, pp. 101 - 110, 2021. DOI: 10.13189/ujar.2021.090401.

(b): Sangsoo Park, Hiroki Nishikoji, Shotaro Takahashi, Oleasegun Olamide Fawibe, Peiwu Wang, Akihiro Isoda (2021). Rice Cultivation under Drip Irrigation with Plastic Film Mulch in the Kanto Area of Japan. Universal Journal of Agricultural Research, 9(4), 101 - 110. DOI: 10.13189/ujar.2021.090401.

Copyright $\bigcirc 2021$ by authors, all rights reserved. Authors agree that this article remains permanently open access under the terms of the Creative Commons Attribution License 4.0 International License

\begin{abstract}
A drip irrigation system with plastic mulch film was evaluated in terms of growth, yield, and water productivity (WP) using three leading paddy rice cultivars (Japonica) in the Kanto area of Japan. A cultivation with drip irrigation and plastic film mulch in the upland field (DI) and continuous flooding cultivation in a paddy field (CF) were conducted in 2015 (DI) and 2016 (DI and CF). The amounts of irrigation and total water supply (irrigation and precipitation) were $715 \mathrm{~mm}, 599 \mathrm{~mm}$, and $905 \mathrm{~mm}$ and $1620 \mathrm{~mm}, 1379 \mathrm{~mm}$, and $1687 \mathrm{~mm}$ for DI in 2015, DI in 2016, and CF in 2016, respectively. The percentages of irrigation for DI in 2015 and 2016 compared to those of $\mathrm{CF}$ were $79 \%$ and $66 \%$, respectively. The grain yields in 2015 were higher than those in 2016 for DI. The DI in 2016 showed significantly lower grain yields compared to those of $\mathrm{CF}$, representing $74 \%$ to $85 \%$ of the $\mathrm{CF}$ which were attributed to lower leaf area indexes in DI. There was no significant difference in WP between $\mathrm{DI}$ and $\mathrm{CF}$, between years and among cultivars, ranging from 0.25 to $0.30 \mathrm{~kg} \mathrm{~m}^{-3}$, showing an offset of the reduction in irrigation water by lower yields in DI. The rice cultivation system under drip irrigation with plastic film mulch showed a large water-saving effect, no physiological damage due to water stress and a slight reduction of grain yield compared to that of the paddy field.
\end{abstract}

Keywords Drip Irrigation, Grain Yield, Paddy Rice,
Photosynthesis, Plastic Film Mulch

\section{Introduction}

As human populations and economies grow, it has become evident in the last few decades that freshwater scarcity is becoming a threat to the sustainable development of human society [1]. It is, therefore, crucial to develop agronomic practices with the potential to reduce water use without reducing agricultural productivity [2]. Rice (Oryza sativa L.) is a staple food for more than $50 \%$ of the world's population, including regions of high population density and rapid growth [3]. The conventional cultivation system of rice is to flood and maintain water in the field, which requires a large amount of water because of water loss through evaporation and percolation.

Several practices are designed to reduce water use and increase water use efficiency in rice cultivation, including saturated soil culture (SSC), alternate wetting and drying (AWD), aerobic rice (AR) and drip irrigation (DI). These systems have also the possibility to reduce global warming potential (GWP), especially that from rice paddy methane emissions, which have been estimated to contribute $15 \%-26 \%$ of the total global anthropogenic 
emissions[4].

In the SSC system, the soil is kept saturated or at slightly below saturation by furrow irrigation between raised beds, with the water level in the furrows ranging between 5 and $30 \mathrm{~cm}$. Borrell et al.[5] and Tabbal et al.[6] reported that SSC saved $32 \%$ and $31 \%$ to $58 \%$ of water compared to conventional flooded systems with small yield reduction, respectively. AWD is an irrigation practice introducing unsaturated soil conditions during the growing season. Bouman and Tuong[7] reported that AWD reduced water inputs by $23 \%$ compared to that of a continuously flooded rice system. In the AR system, specially adapted input-responsive AR varieties are grown under dryland conditions with or without supplemental irrigation[8]. This system could reduce water inputs by $30 \%-50 \%$ with a $20 \%-30 \%$ reduction in yield compared to that in flood systems.

The DI system is defined as the application of water through point or line sources on or below the soil surface at a small operating pressure and a low discharge rate, resulting in partial wetting of the soil surface[9]. This system can apply water both precisely and uniformly at a high irrigation frequency compared to that of furrow and sprinkler irrigation, thus potentially increasing yield, reducing subsurface drainage, and providing better salinity control[10]. The DI system has been adopted widely in cotton cultivation[11][12]. Cetin and Bilgel[13] reported that cotton yield and water use efficiency in DI were higher than those in furrow and sprinkler irrigation. There are also several reports on soybean cultivation using DI showing high water productivities and yields[14]-[17]. In rice, DI system has begun in India[18]-[20] and China[21]-[23], showing high WP and almost similar and/or higher grain yield compared to those of the continuous flood system. However, these trials have just begun and are not established yet. It seems that several problems would remain, including fertilization methods, proper amount and timing of water supply, optimal planting density, and proper cultivars. The growth of the rice plant and its management would also depend on the climatic and soil conditions. It is therefore important to establish water-saving and environmentally friendly cultivation systems for rice under specific climatic and soil conditions. In the Kanto area of Japan, the annual precipitation is sufficient for paddy rice cultivation (around $1500 \mathrm{~mm}$ ), which has been established completely. However, environmentally friendly cultivation systems in rice should be evaluated properly, and established to provide protection against the changes caused by global warming, even in this area. In this experiment, we intended to assess a rice cultivation system with DI and plastic mulch films in the Kanto area of Japan for two years. We appraised this system in terms of growth, yield, and WP using leading paddy rice cultivars (Japonica) in the Kanto area of Japan.

\section{Materials and Methods}

The experiment was conducted at the experimental farm of Faculty of Horticulture, Chiba University in 2015 and 2016. Three rice cultivars (Oryza sativa L., Japonica type), 'Koshihikari', 'Fusaotome', and 'Fusakogane', were used. The experimental fields consisted of an upland field with drip irrigation and plastic film mulch (DI) in 2015 and 2016 and a paddy field with continuous flooding (CF) in 2016. In the previous season of 2015, rye was grown in the DI plot, and hairy vetch (Vicia villosa Roth) was grown in the previous season of 2016. The CF area was divided into nine concrete flamed plots (a plot size was $3.0 \times 2.5 \mathrm{~m}$ and $80 \mathrm{~cm}$ in depth) filled with the same surface soil (about $20 \mathrm{~cm}$ in depth) as that for DI just before the growing season of 2016. One plot of the upland and paddy fields consisted of four and two beds, with four lines covered with a black polyethylene mulch film, respectively (Figure. 1). The polyethylene mulch was removed from the paddy field at the fourth leaf stage when water was flooded, and remained for DI during the growing season. A drip tube with a flow of $0.13 \mathrm{~L} \mathrm{~min}^{-1}$ $\mathrm{m}^{-1}$ (Uni-Ram CN17, Sumika Agricultural Materials Ltd.) was set between two lines. Seeds were coated by a fungicide (Benomyl) before seeding. Five seeds per hill were sown by hand at $5 \mathrm{~cm}$ distance between hills on May 11 in 2015 and June 1 in 2016, respectively. The planting densities were 50.0 and 66.7 hills $\mathrm{m}^{-2}$ for 2015 and 2016, respectively. A combination of $\mathrm{N}, \mathrm{P}_{2} \mathrm{O}_{5}$, and $\mathrm{K}_{2} \mathrm{O}$ was applied at a ratio of 40:40:40 $\mathrm{kg} \mathrm{ha}^{-1}$, respectively, before planting. Additional nitrogen fertilizer $\left(20 \mathrm{~kg} \mathrm{ha}^{-1}\right.$ as urea solution) was sprayed onto the foliage on the 78th and 71 st days after sowing (DAS) in 2015 and 2016, respectively. Irrigation was performed for $1-2 \mathrm{~h}$ when soil moisture content monitored by a soil moisture content meter (DIK-321A, Daiki Rika Kogyo Co., Ltd., Kounosu, Japan) was below $80 \%$ and $70 \%$ during the early growing and flowering stages and below $70 \%$ and $60 \%$ during the other stages in 2015 and 2016, respectively. In CF, 4-5 $\mathrm{cm}$ of the irrigation water was maintained above the ground surface after the fourth leaf stage until two weeks before harvest. Weeds were removed by hand as necessary. No fungicide and pesticide were applied due to no marked symptom of diseases and insects during the growing seasons except the fungicide at seeding.

The experimental plots were arranged in a randomized complete block design with three replications in 2015, and a split-plot design with three replications in 2016. In 2016, the main and subplots consisted of two field treatments (ID and $\mathrm{CF}$ ) and three cultivars, respectively. In this experiment, statistical comparisons were made between DI in 2015 and 2016, and between DI and CF in 2016.

From the fourth leaf stage, the plant height, tiller number, leaf number, and SPAD value were measured at one-week intervals, and the dry matter weights of each organ and leaf area were measured at two-week intervals 
for 10 plants. On July 28 and September 1 in 2016, the $\mathrm{CO}_{2}$ assimilation rate, transpiration rate, stomatal conductance for the three uppermost full expanding leaves per treatment and cultivar were measured using a photosynthetic meter (LI-6400, LI-COR Co., Ltd., Lincoln, USA) from 1000 to $1400 \mathrm{~h}$. On the same days, the actual quantum yield of photosystem II $\left(\Delta \mathrm{F} / \mathrm{F}_{\mathrm{m}}{ }^{\prime}\right)$ and maximum quantum yield of photosystem II $\left(\mathrm{F}_{\mathrm{v}} / \mathrm{F}_{\mathrm{m}}\right)$ for the three uppermost full expanding leaves per treatment and cultivar were measured using a chlorophyll fluorescence meter (PAM-2000, Walz Co., Ltd., Effeltrich, Germany). The measurements of $\Delta \mathrm{F} / \mathrm{F}_{\mathrm{m}}{ }^{\prime}$ and $\mathrm{F}_{\mathrm{v}} / \mathrm{F}_{\mathrm{m}}$ were performed from 1000 to $1400 \mathrm{~h}$ and 2100 to $2200 \mathrm{~h}$, respectively.



Figure 1. Mean air temperature and precipitation. in 2015 and 2016

At maturity, 80 hills per plot were harvested to determine the grain yield and yield components, including the numbers of panicles and spikelets per panicle, percentage filled grains, and grain weight. Filled grains were defined as having a specific gravity $\geq 1.06 \mathrm{~g} \mathrm{~cm}^{-3}$. The unhusked grain yield and grain weight were expressed at $14 \%$ moisture content.

The meteorological data used, including mean air temperature and precipitation, were collected in Funabashi (about $10 \mathrm{~km}$ distance from the experimental site) by the Japan Meteorological Agency.

\section{Results}

\subsection{Weather Conditions and the Amount of Water Supplied}

The mean air temperature in 2015 was low from June to early July owing to continuous rainy days, and increased drastically in the middle of July. The high air temperature continued for one month, then decreased rapidly after the middle of August compared to that in an average year (Figure 1). In 2016, the mean air temperature change was lower with time compared to that in the average year during the growing season but was higher after September.
The precipitation in 2015 was low from May to June, and increased in early July. From the middle of July to early August, the amount of precipitation was low but increased remarkably in early September. In 2016, the precipitation was relatively higher than that in 2015 during the period from May to June. The amount of precipitation change was lower from July to early August compared to that in 2015. After the middle of August, the amount of precipitation was relatively high.
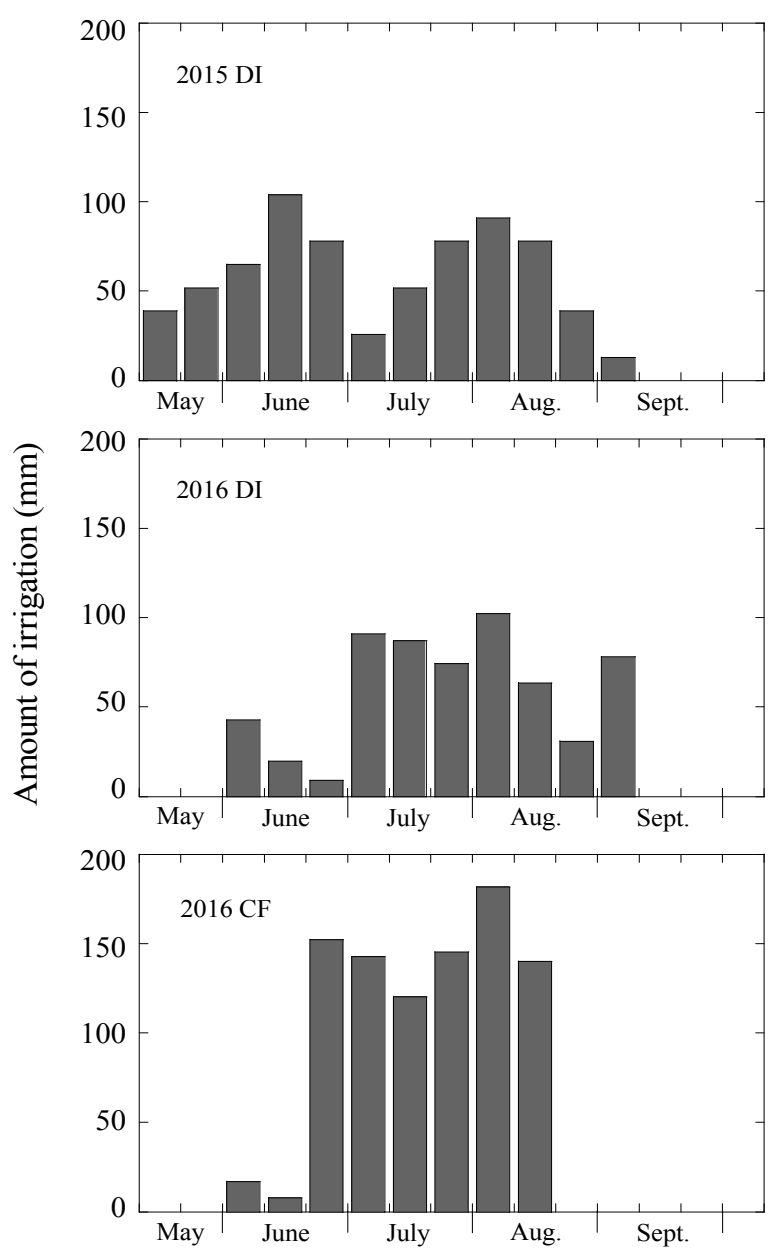

DI and CF indicate upland field with drip irrigation and paddy field with continuous flooding, respectively.

Figure 2. Amount of irrigation in 2015 and 2016

Figure 2 shows the amount of irrigation for DI in 2015 and 2016 and CF in 2016. The amount of precipitation during the growing season was $905 \mathrm{~mm}$ and $780 \mathrm{~mm}$ for 2015 and 2016, respectively. The amounts of irrigation were $715 \mathrm{~mm}, 599 \mathrm{~mm}$, and $905 \mathrm{~mm}$ for DI in 2015, DI in 2016 and CF in 2016, respectively. The total water supply (irrigation and precipitation) for DI in 2015 and 2016 and CF in 2016 were $1620 \mathrm{~mm}, 1379 \mathrm{~mm}$, and $1687 \mathrm{~mm}$, respectively. The percentages of the total water supply used for DI in 2015 and 2016 compared to those used for CF were $96 \%$ and $81 \%$, respectively. The percentages of irrigation used for DI in 2015 and 2016 compared to those used for CF were $79 \%$ and $66 \%$, respectively. 


\subsection{Plant Height, Tiller Number, SPAD Value, and Leaf Area Index (LAI)}

The plant height in Koshihikari was higher than those in Fusaotome and Fusakogane (Figure 3). The plant height for $\mathrm{CF}$ in Koshihikari was higher than those for DI. The difference between them was approximately $10-20 \mathrm{~cm}$ in the later growing season. The plant height reached the maximum at around 100 DAS for every treatment. The plant height in CF was also higher for Fusaotome than in DI. For the upland field in 2016, however, the plant height was similar to that in $\mathrm{CF}$ in the late growing season. Fusakogane showed a similar tendency to Fusaotome; the plant height in CF was higher than that in DI.
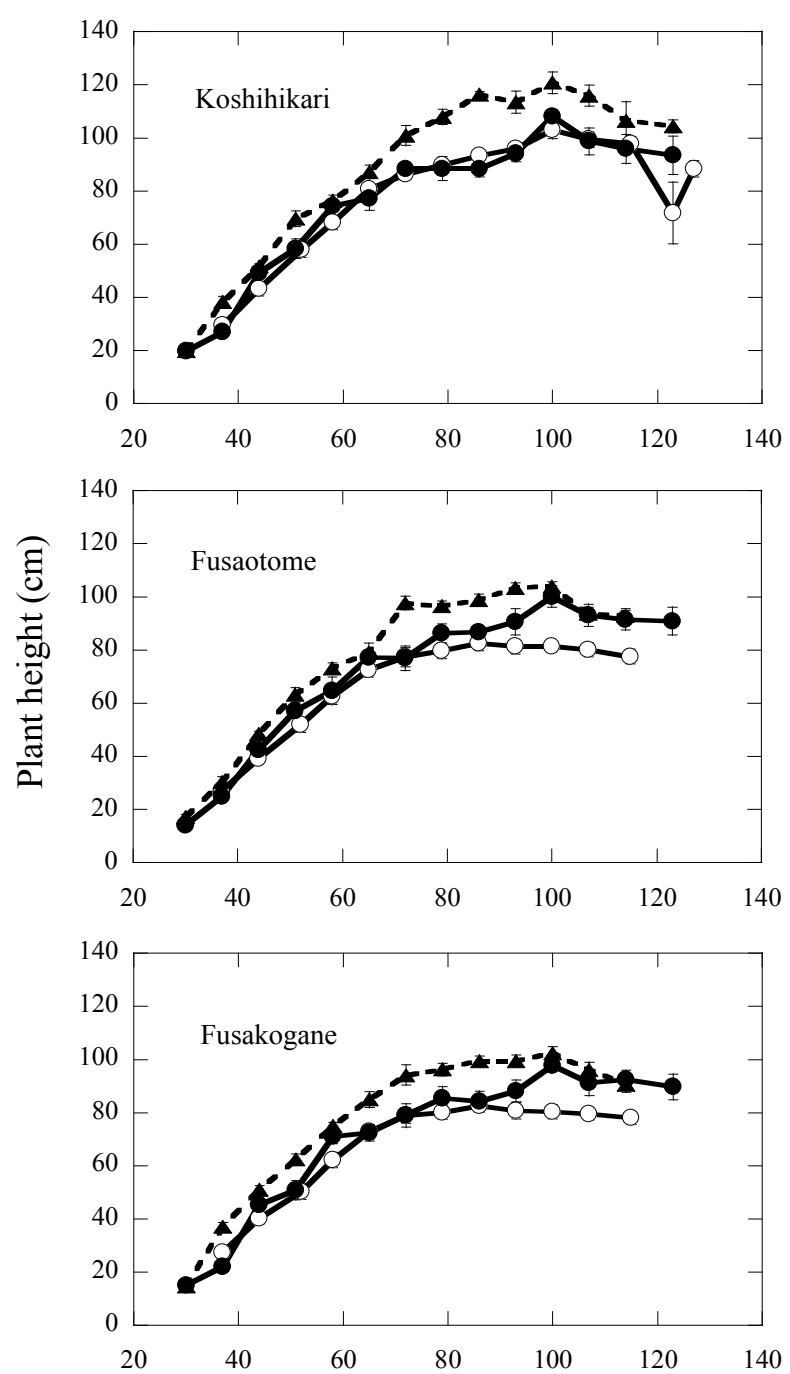

Bars indicate standard deviations.

$\circ$ : upland field with drip irrigation in $2015, \bullet$ : upland field with drip irrigation in 2016 and $\boldsymbol{\Lambda}$ : paddy field with continuous flooding in 2016.

Figure 3. Changes with time in plant height
The tiller number per hill was higher for DI in 2015 compared to that in 2016 and the paddy field, especially for Koshihikari, due to the low planting density in 2015 . In 2016, CF had higher values than DI for every cultivar.

The SPAD values for DI in 2016 were lower in Koshihikari, though it recovered slightly after topdressing with nitrogen (Figure 4). DI in 2016 showed similar values to those in CF in Koshihikari. DI in both years had higher values than $\mathrm{CF}$ in the former half of the growing season, then decreased for DI in 2016. The SPAD values for DI in 2015 were kept high throughout the growing season in Fusakogane. CF and DI in 2016 showed relatively low values in the former half of the growing season, then increased and decreased their values, respectively.
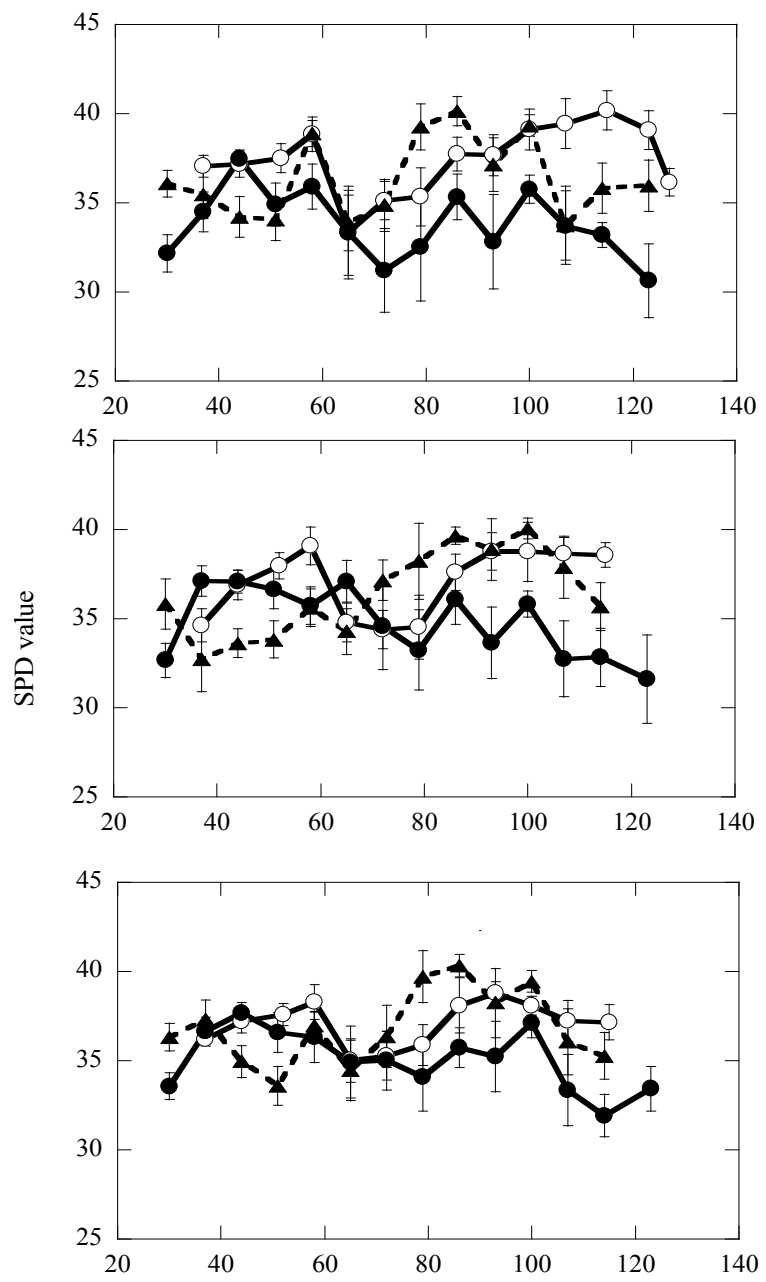

Bars indicate standard deviations.

$\circ$ : upland field with drip irrigation in $2015, \bullet$ : upland field with drip irrigation in 2016 and $\boldsymbol{\Delta}$ : paddy field with continuous flooding in 2016 .

Figure 4. Changes with time in SPAD value 

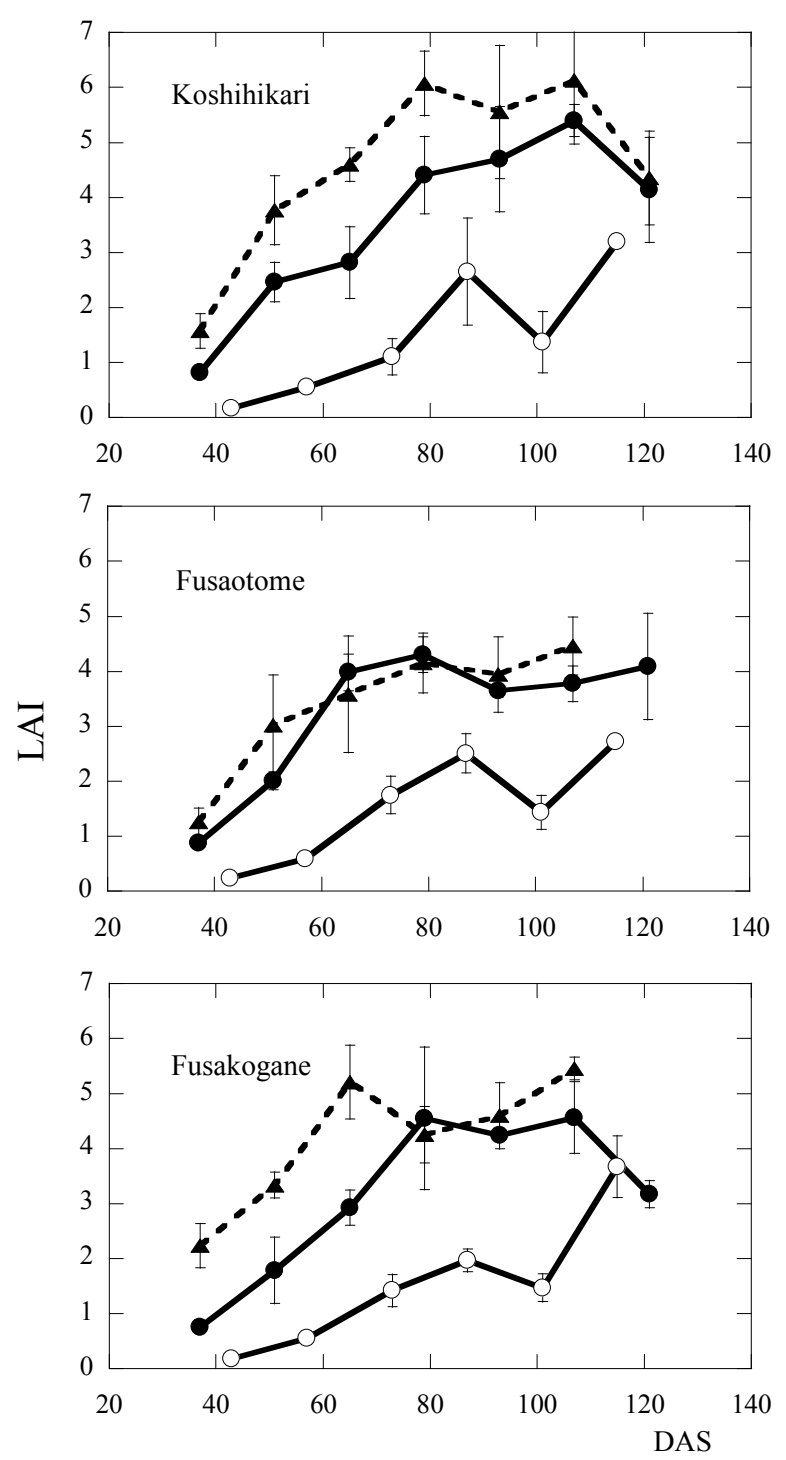

Bars indicate standard deviations.

$\circ$ : upland field with drip irrigation in $2015, \bullet$ : upland field with drip irrigation in 2016 and $\boldsymbol{\Delta}$ : paddy field with continuous flooding in 2016.

Figure 5. Changes with time in leaf area index (LAI).
Figure 5 shows changes in LAI for two years in the upland and paddy fields. For Koshihikari, LAI in CF was always higher than those in DI for both years. The maximum LAI was attained at 79 DAS for CF, being 6.1. In contrast, the LAI for DI in 2015 was always lower than in the other treatments. The LAIs for DI in 2016 were higher and lower than those for DI in 2015 and CF in 2016, respectively. The maximum value was attained in the later growing season at 107 DAS. Fusaotome had lower LAIs than did Koshihikari, with around 4 being the maximum value. Although the LAI for CF was higher than that for DI in the early growing season, the LAI of DI in 2016 was similar to that of CF. The LAI of DI in 2015 was lowest during the growing season. The LAI of CF in Fusakogane was higher than those of DI in the first half of the growing season. The LAI of DI in 2016 increased to a similar value to those of CF. The maximum LAI was attained at the later growing season for every treatment.

\subsection{Photosynthesis and Its Related Characteristics}

There was no significant difference between DI and CF in $\mathrm{CO}_{2}$ assimilation rates on July 28; although there was a trend, the values were slightly higher in CF (Table 1). No varietal differences were found in the $\mathrm{CO}_{2}$ assimilation rates of both fields. The stomatal conductance and transpiration rates in $\mathrm{CF}$ were significantly higher than those in DI. Although there was no significant varietal difference among the cultivars in the stomatal conductance of DI and the transpiration rate of both fields, Fusaotome and Koshihikari had higher stomatal conductances than did Fusakogane in CF. The stomatal conductance in CF was significantly higher than that in DI. Varietal differences among the cultivars were found only in DI. The transpiration rate was also significantly higher in CF. There was no significant difference between the fields and among the cultivars with regard to the photochemical reaction measurements $\Delta \mathrm{F} / \mathrm{F}_{\mathrm{m}}{ }^{\prime}$ and $\mathrm{F}_{\mathrm{v}} / \mathrm{F}_{\mathrm{m}}$. $\Delta \mathrm{F} / \mathrm{F}_{\mathrm{m}}{ }^{\prime}$ and $\mathrm{F}_{\mathrm{v}} / \mathrm{F}_{\mathrm{m}}$ showed around 0.65 and 0.80 for all cultivars of both fields, respectively. The leaf water potential (LWP) in CF was significantly higher than that in DI. There was no significant difference among the cultivars in LWP in both DI and CF. 
Table 1. Characteristics related with photosynthesis and leaf water potential on July 28 and September 1, 2016

\begin{tabular}{|c|c|c|c|c|c|c|c|c|c|c|c|c|}
\hline \multirow[t]{2}{*}{ Cultivar } & \multicolumn{2}{|c|}{$\begin{array}{c}\mathrm{CO}_{2} \text { assimilation rate } \\
\left(\mu \mathrm{mol} \mathrm{m}{ }^{-2} \mathrm{~s}^{-1}\right)\end{array}$} & \multicolumn{2}{|c|}{$\begin{array}{c}\text { Stomatal conductance } \\
\left(\mathrm{mmol} \mathrm{m}{ }^{-2} \mathrm{~s}^{-1}\right)\end{array}$} & \multicolumn{2}{|c|}{$\begin{array}{c}\text { Transpiration rate } \\
\left(\mathrm{mmol} \mathrm{m}{ }^{-2} \mathrm{~s}^{-1}\right)\end{array}$} & \multicolumn{2}{|c|}{$\begin{array}{c}\text { Actual } \\
\text { quantum yield of PSII }\end{array}$} & \multicolumn{2}{|c|}{$\begin{array}{l}\text { Maximum quantum yield } \\
\text { of PSII }\end{array}$} & \multicolumn{2}{|c|}{$\begin{array}{l}\text { Leaf water } \\
\text { potential } \\
\text { (MPa) }\end{array}$} \\
\hline & DI & $\mathrm{CF}$ & DI & $\mathrm{CF}$ & DI & $\mathrm{CF}$ & DI & $\mathrm{CF}$ & DI & $\mathrm{CF}$ & DI & $\mathrm{CF}$ \\
\hline \multicolumn{13}{|l|}{ July 28} \\
\hline Koshihikari & 16.6 & 17.8 & 149 & $309 a$ & 2.48 & 3.00 & 0.635 & 0.678 & 0.789 & 0.809 & -2.28 & -2.13 \\
\hline Fusaotome & 16.3 & 18.4 & 141 & $323 a$ & 2.45 & 3.51 & 0.665 & 0.682 & 0.792 & 0.817 & -2.25 & -2.03 \\
\hline Fusakogane & 16.9 & 17.8 & 153 & $283 b$ & 2.54 & 3.04 & 0.657 & 0.666 & 0.805 & 0.811 & -2.23 & -2.00 \\
\hline $\begin{array}{l}\text { Significance between } \\
\text { fields }\end{array}$ & \multicolumn{2}{|c|}{ ns } & \multicolumn{2}{|c|}{$* *$} & \multicolumn{2}{|c|}{$*$} & \multicolumn{2}{|c|}{$\mathrm{ns}$} & \multicolumn{2}{|c|}{$\mathrm{ns}$} & \multicolumn{2}{|c|}{$*$} \\
\hline \multicolumn{13}{|l|}{ September 1} \\
\hline Koshihikari & 17.7 & 20.1 & $250 \mathrm{ab}$ & 352 & $4.08 \mathrm{a}$ & $3.71 \mathrm{~b}$ & 0.656 & $0.665 b$ & 0.792 & 0.804 & $-2.38 b$ & -2.15 \\
\hline Fusaotome & 16.9 & 19.4 & $253 \mathrm{a}$ & 354 & $3.87 \mathrm{~b}$ & $3.94 \mathrm{a}$ & 0.659 & $0.661 \mathrm{~b}$ & 0.793 & 0.795 & $-2.31 b$ & -2.08 \\
\hline Fusakogane & 16.4 & 19.4 & $229 b$ & 326 & $3.95 \mathrm{ab}$ & $3.61 \mathrm{c}$ & 0.659 & $0.685 \mathrm{a}$ & 0.796 & 0.802 & $-2.18 \mathrm{a}$ & -1.97 \\
\hline $\begin{array}{l}\text { Significance between } \\
\text { fields }\end{array}$ & \multicolumn{2}{|c|}{$* *$} & \multicolumn{2}{|c|}{$* *$} & \multicolumn{2}{|c|}{$* *$} & \multicolumn{2}{|c|}{ ns } & \multicolumn{2}{|c|}{ ns } & \multicolumn{2}{|c|}{ * } \\
\hline
\end{tabular}

DI and CF indicate upland field with drip irrigation and paddy field with continuous flooding, respectively.

$*, * *$ and ns indicate $5 \%, 1 \%$ levels of significance and no significance, respectively.

Values in each column followed by the same letter are not significantly different at $\mathrm{P}<0.05$.

\begin{tabular}{|c|c|c|c|c|c|c|c|c|c|c|c|c|c|c|c|c|c|c|}
\hline \multirow[t]{2}{*}{ Cultivar } & \multicolumn{3}{|c|}{$\begin{array}{l}\text { Panicle number } \\
\qquad\left(\mathrm{m}^{-2}\right)\end{array}$} & \multicolumn{3}{|c|}{$\begin{array}{c}\text { Grain number } \\
\left(\text { panicle }^{-1}\right)\end{array}$} & \multicolumn{3}{|c|}{$\begin{array}{c}\text { Ripening percentage } \\
(\%)\end{array}$} & \multicolumn{3}{|c|}{$\begin{array}{l}1000 \text { grain weight } \\
(\mathrm{g})\end{array}$} & \multicolumn{3}{|c|}{$\begin{array}{l}\text { Grain yield } \\
\left(\mathrm{g} \mathrm{m}^{-2}\right)\end{array}$} & \multicolumn{3}{|c|}{$\begin{array}{l}\text { Water productivity } \\
\qquad\left(\mathrm{kg} \mathrm{m}^{-3}\right)\end{array}$} \\
\hline & $\mathrm{DI}^{1}$ & $\mathrm{DI}^{2}$ & $\mathrm{CF}$ & $\mathrm{DI}^{1}$ & $\mathrm{DI}^{2}$ & $\mathrm{CF}$ & $\mathrm{DI}^{1}$ & $\mathrm{DI}^{2}$ & $\mathrm{CF}$ & & $\mathrm{DI}^{1}$ & $\mathrm{DI}^{2}$ & $\mathrm{CF}$ & $\mathrm{DI}^{1}$ & $\mathrm{DI}^{2}$ & $\mathrm{CF}$ & $\mathrm{DI}^{1}$ & $\mathrm{DI}^{2}$ \\
\hline Koshihikari & 440 & 387 & 414 & $76.3 \mathrm{a}$ & 82.4 & 80.7 & $58.1 \mathrm{~b}$ & $60.6 \mathrm{~b}$ & 65.6 & $21.5 b$ & $22.3 \mathrm{c}$ & 23.3 & 468 & 378 & 479 & 0.29 & 0.25 & 0.26 \\
\hline Fusaotome & 445 & 323 & 371 & $62.3 b$ & 69.6 & 83.4 & $78.2 \mathrm{a}$ & $77.6 \mathrm{a}$ & 75.5 & $21.3 b$ & $23.3 \mathrm{a}$ & 24.1 & 472 & 392 & 530 & 0.29 & 0.26 & 0.29 \\
\hline Fusakogane & 435 & 366 & 388 & $64.6 \mathrm{ab}$ & 65.6 & 69.2 & $79.9 \mathrm{a}$ & $74.2 \mathrm{a}$ & 73.9 & $22.3 \mathrm{a}$ & $22.7 \mathrm{~b}$ & 23.8 & 484 & 391 & 459 & 0.30 & 0.26 & 0.25 \\
\hline \multicolumn{19}{|l|}{$\begin{array}{l}\text { Significance } \\
\text { between }\end{array}$} \\
\hline years & & $*$ & & & $*$ & & & $\mathrm{~ns}$ & & & $*$ & & & $\mathrm{~ns}$ & & & $\mathrm{~ns}$ & \\
\hline fields & & $*$ & & & ns & & & $\mathrm{ns}$ & & & $*$ & & & $*$ & & & $\mathrm{~ns}$ & \\
\hline
\end{tabular}

$\mathrm{DI}^{1}, \mathrm{DI}^{2}$ and $\mathrm{CF}$ indicate upland field with drip irrigation in 2015, upland field with drip irrigation system in 2016 and paddy field with continuous flooding, respectively.

* and ns indicate $5 \%$ level of significance and no significance, respectively.

Values in each column followed by the same letter are not significantly different at $\mathrm{P}<0.05$. 
On September 1, CF showed higher $\mathrm{CO}_{2}$ assimilation rates than did DI. There was no significant difference among the cultivars in both fields. The transpiration rate was also higher in CF. Koshihikari and Fusaotome had the highest transpiration rates in $\mathrm{DI}$ and $\mathrm{CF}$, respectively. There was no significant difference between $\mathrm{DI}$ and $\mathrm{CF}$, and among the cultivars in $\Delta F / F_{m}{ }^{\prime}$ and $F_{v} / F_{m}$, being around 0.66 and 0.80 , respectively. The leaf water potential (LWP) in CF was significantly higher than that in DI. Fusakogane had the highest LWP in DI, though there was no varietal difference in $\mathrm{CF}$.

\subsection{Yield, Yield Components, and Water Productivity (WP)}

Panicle numbers of DI in 2015 were the highest among the three treatments (Table 2). DI in 2015 showed higher values than those in 2016. However, DI in 2016 showed lower values than those in CF in 2016. There was no significant difference in grain number per panicle between DI and CF in 2016, although there was a significant difference between the two years for DI, showing higher values in 2016. For the ripening percentage, there was no significant difference between two years and between DI and $\mathrm{CF}$, showing relatively lower values. Grain weight in DI in 2016 was significantly higher than that in 2015. CF had higher values than did DI in 2016. The grain yields in 2015 were higher than those in 2016 for DI. In 2016, DI showed significantly lower values than did $\mathrm{CF}$, representing $79 \%, 74 \%$, and $85 \%$ of the CI for Koshihikari, Fusaotome, and Fusakogane, respectively. The highest value in DI was obtained by Fusakogane in 2015, showing $484 \mathrm{~g} \mathrm{~m}^{-2}$. There were no significant differences in WP between DI and CF, between years, nor among cultivars, ranging from 0.25 to $0.30 \mathrm{~kg} \mathrm{~m}^{-3}$, showing an offset of the reduction in irrigation water by lower yields in DI.

\section{Discussion}

In this experiment, grain yields with more than $400 \mathrm{~g}$ $\mathrm{m}^{-2}$ and $300 \mathrm{~g} \mathrm{~m}^{-2}$ were obtained in 2015 and 2016 for DI respectively, which were slightly lower than that of $\mathrm{CF}$ in 2016. From the viewpoint of yield components, the smaller numbers of tillers in DI for the three cultivars were one of the main reasons for the lower yield in DI compared to that in CF. It was reported that the tiller numbers under lower soil moisture conditions were lower than those in the flood irrigation system[24] and those under a higher soil moisture condition[25]. Dou et al.[26] also showed that the panicle numbers in aerobic and saturated soil conditions were smaller than those in the flood irrigation system. The smaller number of tillers would also lead to lower LAIs in DI. Almost LAIs in DI were lower than those in $\mathrm{CF}$ during the growing seasons.
Yoshida[27] reported that the crop growth rate reached a maximum at an LAI of about 6 for an erect type variety (IR8). Sinclair and Sheehy[28] suggested that a benefit of erect leaves in light interception would obtain with LAI greater than 4.2. The LAIs of DI, especially in 2015, were less than 4 . This would be another reason for a relatively lower yield in DI compared to that in CF. However, this disadvantage in DI could be overcome, and it would be possible to increase LAIs near the optimum LAI by modifying the planting populations and patterns in DI, e.g., the distances between mulches and/or rows and mulch sizes, since there were still uncovered areas by leaves in DI and DI showed a higher lodging resistance than did CF.

In drought-stressed rice, the photosynthetic capacity decreased as a result of stomatal closure as an early and effective response to water deficit[29][30]. The stomatal conductance and LWP in DI were significantly lower than those in $\mathrm{CF}$, leading to lower values in terms of both $\mathrm{CO}_{2}$ assimilation rates and transpiration rates. In contrast, no significant difference was found between the actual and maximum quantum yields of PSII, indicating that there would be no market photoinhibition in DI due to water stress. The lower growth and yield in DI might be attributed to the lower efficiency in the carbon reaction of photosynthesis due to lower values of stomatal conductance in DI, though this reduction was not as significant when compared to the growth in CF.

In general, $1200 \mathrm{~mm}$ to $1500 \mathrm{~mm}$ of irrigation is required for a paddy field during the growing season in Japan. It was reported that a direct seeding cultivation method needed more than $1200 \mathrm{~mm}$ of irrigation for a paddy field in Chiba Prefecture[31]. In this experiment, the amounts of irrigation were $715 \mathrm{~mm}, 599 \mathrm{~mm}$, and 905 $\mathrm{mm}$ for DI in 2015, DI in 2016, and CF in 2016, respectively, which were very lower than the general values in Japan and those of a previous report from Chiba Prefecture. The paddy field used in this experiment was made of concrete flamed blocks. The water percolation from the bottom and sides of the concrete flames to the soil must be less than that in ordinary paddy fields. There is a possibility that the amount of irrigation could be underestimated for CF in 2016. Therefore, this cultivation method could use approximately 50\% less irrigation than the ordinary cultivation method for a paddy field in Japan. Otherwise, there was no difference in WP between CF and DI in 2016. The reasons for this insignificance might be caused by the underestimation of irrigation for CF due to less water percolation to the ground, the large amount of precipitation in both years, and the relatively lower yield in DI than that in CF. Kamoshita et al.[32] reported that the WP in CF and the non-flooded condition with transplanting varied from 0.077 to $0.117 \mathrm{~kg} \mathrm{~m}^{-3}$ and 0.147 to $0.183 \mathrm{~kg} \mathrm{~m}^{-3}$, respectively in Tokyo, the Kanto area of Japan. The WP values obtained in this experiment were higher than their records, showing the advantages of DI in 
terms of WP compared to other non-flooded or flooded conditions in the Kanto area of Japan. Tuong et al.[33] summarized the WP of rice in Asia. The most frequently recorded WP was from 0.2 to $0.4 \mathrm{~kg} \mathrm{~m}^{-3}$, including India, with local varieties on light soils and a deep groundwater table, while higher values of more than $1.0 \mathrm{~kg} \mathrm{~m}^{-3}$ were recorded in China with hybrid rice cultivars on clay soil and a shallow groundwater table. As a comparison with their review of WPs, the WP values obtained in the Kanto area of Japan, including those from both the study of Kamoshita and this experiment, might be underestimated because of the large amount of precipitation in spite of a relatively high yield.

Some experiments showed higher grain yields in AWD using transplanting and high yielding cultivars, including a hybrid[34] in a ground cover rice production system (GCRPS) using transplanting[35], which applied more than twice as much nitrogen as this experiment. In contrast, the grain yields in DI obtained in this experiment using direct seeding are comparable with the other water-saving cultivations reported by Ramulu et al.[36] in aerobic cultivation with DI, Jabran et al.[37] using mulching, and Rao et al.[38] in a system of rice intensification. Luo[39] reported that water-saving and drought-tolerant rice varieties have been bred in China; otherwise, this cultivation system shows that it is possible to obtain comparable yields using not specific drought-tolerant cultivars, but commercial cultivars. The used cultivars in this experiment are not particularly drought tolerant. Koshihikari has been the most popular cultivar for paddy fields in Japan for the past four decades, and Fusaotome and Fusakogane are also popular. This cultivation system showed the potential for such commercial paddy cultivars to obtain similar yields to those observed under paddy field conditions in addition to saving a significant amount of water. Therefore, genotypes with suitable traits could be found for this cultivation system, further high yields and water productivities would be expected.

This cultivation system has other possibilities, including no need to bring a soil surface to a level as a paddy field, and easy management for cultivation. Frequent liquid fertigation via drip tubes would be also effective in sterile soil conditions such as marginal areas of deserts, where the soil doesn't have a preservation ability of nutrients and water. In addition, the reduction of greenhouse gas emissions, including those of $\mathrm{CH}_{4}, \mathrm{~N}_{2} \mathrm{O}$, and $\mathrm{CO}_{2}$ is one of these potentialities. Fawibe et al.[40] reported that GHG emissions in DI was $2.2 \%$ in CF. Therefore, this cultivation system is an effective system for not only saving water but also preventing global warming.

\section{Conclusions}

The rice cultivation system under drip irrigation with plastic film mulch showed a large water-saving effect, no physiological damage due to water stress and a slight reduction of grain yield compared to that of the paddy field. This cultivation system must be one of the promising systems for saving water and preventing global warming, although there is room for improving cultivation methods including planting density.

\section{Acknowledgment}

This work was supported by JSPS KAKENHI Grant Number JP16K07570.

\section{REFERENCES}

[1] Mekonnen M.M., Hoekstra A.Y., "Four billion people facing severe water scarcity," Science Advances vol. 2, no. 2, pp. 1-6, 2016. DOI: $10.1126 /$ sciadv. 1500323

[2] Carrijo D.R., Lundy M.E., Linquist B.A., "Rice yields and water use under alternate wetting and drying irrigation: A meta-analysis,". Field Crops Research vol. 203, pp. 173-180, 2017. https://doi.org/10.1016/j.fcr.2016.12.002

[3] Fageria N.K., "Yield physiology of rice," Journal of Plant Nutrition vol. 30, no. 6, pp. 843-879, 2007. https://doi.org/10.1080/15226510701374831

[4] Denman K.L., Brasseur G., Chidthaisong A., Ciais P., Cox P.M., Dickinson R.E., Hauglustaine D., Heinze C., Holland E., Jacob D., Lohmann U., Ramachandran S., da Silva Dias P.L., Wofsy S.C., Zhang X., "Couplings Between Changes in the Climate System and Biogeochemistry" in Climate Change 2007: The Physical Science Basis". Contribution of Working Group I to the Fourth Assessment Report of the Intergovernmental Panel on Climate Change, Cambridge University Press, 2007, pp. 500-587.

[5] Borrell A., Garside A., Fukai S., "Improving efficiency of water use for irrigated rice in a semi-arid tropical environment", Field Crops Research, vol. 52, no. 3, pp. 231-248

1997. https://doi.org/10.1016/S0378-4290(97)00033-6

[6] Tabbal D.F., Bouman B.A.M., Bhuiyan S. I., Sibayan E.B., Sattar M.A., "On-farm strategies for reducing water input in irrigated rice; case studies in the Philippines," Agricultural Water Management, vol. 56, no. 2, pp. 93-112, 2002. https://doi.org/10.1016/S0378-3774(02)00007-0

[7] Bouman B.A.M., Tuong T.P., "Field water management to save water and increase its productivity in irrigated lowland rice," Agricultural Water Management, vol. 49, vol. 1, pp. $11-30, \quad 2001$. https://doi.org/10.1016/S0378-3774(00)00128-1

[8] Bouman B.A.M., Humphreys E., Tuong T.P., Barker R., "Rice and water," Advance in Agronomy, vol. 92, pp. 187-237, 2007. https://doi.org/10.1016/S0065-2113(04)92004-4

[9] Dasberg S., Or D., "Drip irrigation," Springer, pp. 
$1-162.1999$.

[10] Hanson B., May D., "The effect of drip line placement on yield and quality of drip-irrigated processing tomatoes," Irrigation Drainage Systems, vol. 21, pp. 109-118, 2007. https://doi.org/10.1007/s10795-007-9023-5

[11] Constable G.A., Hodgson A.S., "A comparison of drip and furrow irrigated cotton on a cracking clay soil," Irrigation $\begin{array}{llll}\text { Science, vol. 11, pp. 149-153, } 1990 . & .\end{array}$ https://doi.org/10.1007/BF00189452

[12] Ibragimov N., Evett S.R., Esanbekov Y., Kamilov B.S., Mirzaev L., Lamers J.P.A., "Water use efficiency of irrigated cotton in Uzbekistan under drip and furrow irrigation," Agricultural Water Management, vol. 90, no. $1-2, \quad$ pp. $112-120, \quad 2007$ https://doi.org/10.1016/j.agwat.2007.01.016

[13] Cetin O., Bilgel L., "Effects of different irrigation methods on shedding and yield of cotton," Agricultural Water Management, vol. 54, no. 1, pp. 1-15, 2002. https://doi.org/10.1016/S0378-3774(01)00138-X

[14] Isoda A., Mao H., Li Z., Wang P., "Growth of high-yielding soybeans and its relation to air temperature in Xinjiang, China," Plant Production Science., vol. 13, no. 2, pp. 209-217, 2010. https://doi.org/10.1626/pps.13.209

[15] Irmak S., Specht J.E., Odhiambo L.O., Rees J.M., Cassman K.G., "Soybean yield, evapotranspiration, water productivity, and soil water extraction response to subsurface drip irrigation and fertigation," Transactions of the ASABE, vol. 57, no. 3, pp. 729-748, 2014. DOI: $10.13031 /$ trans.57.10085

[16] Adeboye O., Schultz B., Adekalu K., Prasad K., "Crop water productivity and economic evaluation of drip-irrigated soybeans (Glycine max L. Merr.)," Agriculture \& Food Security, vol. 4, no. 10, 2015. DOI: 10.1186/s40066-015-0030-8

[17] Ospanbayev Z.O., Kurmanbayeva M.S., Abdukadirova Z.A., Doszhanova A.S., Nazarbekova S.T., Inelova Z.A., Ablaikhanova N.T., Kenenbayev S.B., Musina A.S., "Water use efficiency of rice and soybean under drip irrigation with mulch in the south-east of Kazakhstan," Applied Ecology and Environmental Research, vol. 15, no. 4, pp. 1581-1603, 2017. http://dx.doi.org/10.15666/aeer/1504_15811603

[18] Parthasarathi T., Mohandass S., Senthilvel S., Vered E., "Effect of drip irrigation systems on yield of aerobic rice," Environment \& Ecology vol. 31, pp. 1826-1829, 2013. https://drive.google.com/file/d/1Cv_wQ_sqzRkChY_pxxk 31IUdGCXWvAEy/view

[19] Tajane V., Gulghane A., Page A., "Drip and paired row planting for paddy cultivation," 2nd World Irrigation Forum, pp. 1-8. 2016.

[20] Kombali G., Nagaraju, Sheshadri T., Thimmegowda M.N., Mallikarjuna G.B., "Economic feasibility of growing aerobic rice under drip fertigation," International Journal of Pure \& Applied Bioscience, vol. 5, no. 2, pp. 854-857, 2017. http://dx.doi.org/10.18782/2320-7051.2676

[21] He H., Ma F., Yang R., Chen L., Jia B., Cui J., Fan H., Wang X., Li L., "Rice performance and water use efficiency under plastic mulching with drip irrigation," $\begin{array}{llll}\text { PLOS ONE, } & \text { vol. } & \text { 8, } & \end{array}$ https://doi.org/10.1371/journal.pone.0083103

[22] He H., Yang R., Chen L., Fan D., Wang X., Wang S. Y., Cheng D.W. Ma F.Y., 2014. "Rice root system spatial distribution characteristics at flowering stage and grain yield under plastic mulching drip irrigation (PMDI)," Journal of Animal \& Plant Sciences, vol. 24, no. 1, pp. 290-301, http://www.thejaps.org.pk/docs/v-24-1/41.pdf

[23] Adekoya M.A., Liu Z., Vered E., Zhou L., Kong D., Qin J., Ma R., Yu X., Liu G., Chen L., Luo L., "Agronomic and ecological evaluation on growing water-saving and drought-resistant rice (Oryza sativa L.) through drip irrigation," Journal of Agricultural Science, vol. 6, no. 5, pp. 110-119, 2014. http://dx.doi.org/10.5539/jas.v6n5p110

[24] Tao H., Dittert K., Zhang L., Lin S., Römheld V., Sattelmacher B., "Effects of soil water content on growth, tillering, and manganese uptake of lowland rice grown in the water-saving ground-cover rice-production system (GCRPS)," Journal of Plant Nutrition and Soil Science, vol. 170, no. 1, pp. 7-13, 2007. https://doi.org/10.1002/jpln.200625033

[25] Hamoud Y.A., Guo X., Wang Z., Chen S., Rasool G., "Effects of irrigation water regime, soil clay content and their combination on growth, yield, and water use efficiency of rice grown in South China," International Journal of Agricultural and Biological Engineering, vol. 11, no. 4 , pp. 144-155, 2018. DOI: 10.25165/j.ijabe.20181104.3895

[26] Dou F., Soriano J., Tabien R.E., Chen K., "Soil texture and cultivar effects on rice (Oryza sativa L.) grain yield, yield components and water productivity in three water regimes," PLOS ONE, 2016. https://doi.org/10.1371/journal.pone.0150549

[27] Yoshida S., "Fundamentals of rice crop science," IRRI, 1981. http://books.irri.org/9711040522_content.pdf

[28] Sinclair T.R., Sheehy J. E., "Erect leaves and photosynthesis in rice," Science, vol. 283, no. 5407, pp. 1455-1456, 1999. DOI: $10.1126 /$ science.283.5407.1455c

[29] Chaves M.M., Pereira J.S., Maroco J., Rodrigues M.L., Ricardo C.P.P., Osorio M.L., Carvalho I., Faria T., Pinheiro C., "How plants cope with water stress in the field? Photosynthesis and growth," Annals of Botany, vol.89, no. 7, pp. 907-916, 2002. https://doi.org/10.1093/aob/mcf105

[30] Lawlor D.W., Cornic G., "Photosynthetic carbon assimilation and associated metabolism in relation to water deficits in higher plants," Plant, Cell \& Environment, vol. 25, no. 2, pp. 275-294, 2002. https://doi.org/10.1046/j.0016-8025.2001.00814.x

[31] Chiba prefecture, Annual report of Chiba Prefectural Agricultural Experimental Station. 2000. https://www.pref.chiba.lg.jp/ninaite/shikenkenkyuu/docum ents/66_3.pdf (accessed Jan. 20, 2021)

[32] Kamoshita A., Ishikawa M., Abe J., Imoto H., "Evaluation of water-saving rice-winter crop rotation system in a suburb of Tokyo," Plant Production Science, vol. 10, no. 2, pp. 219-231, 2007. https://doi.org/10.1626/pps.10.219

[33] Tuong T.P., Bouman B.A.M., Mortimer M., "More rice, 
less water- Integrated approaches for increasing water productivity in irrigated rice-based systems in Asia," Plant Production Science, vol.8, no. 3, pp. 231-241, 2005. https://doi.org/10.1626/pps.8.231

[34] Liang K., Zhong X., Huang N., Lampayan R M., Pan J., Tian K., Liu Y., "Grain yield, water productivity and $\mathrm{CH} 4$ emission of irrigated rice in response to water management in south China," Agricultural Water Management, vol. 163, pp. 319-331, 2016. https://doi.org/10.1016/j.agwat.2015.10.015

[35] Tao Y., Zhang Y., Jin X., Saiz G., Jing R., Guo L., Liu M., Shi J., Zuo Q., Tao H., Butterbach-Bahl K., Dittert K., Lin S., "More rice with less water -evaluation of yield and resource use efficiency in ground cover rice production system with transplanting," European Journal of Agronomy, vol. 68, pp. 13-21, 2015. https://doi.org/10.1016/j.eja.2015.04.002

[36] Ramulu V., Rao V.P., Devi M.U., Kumar K.A., Radhika K., "Evaluation of drip irrigation and fertigation levels in aerobic rice for higher water productivity," in 2nd World Irrigation Forum, pp. 1-9, 2016.
[37] Jabran K., Ullah E., Hussain M., Farooq M., Zaman U., Yaseen M., Chauhan B.S., "Mulching improves water productivity, yield and quality of fine rice under water-saving rice production systems," Journal of Agronomy and Crop Science, vol. 201, no. 5, pp. 389-400, 2015. https://doi.org/10.1111/jac.12099

[38] Rao K.V.R., Gangwar S., Keshri R., Chourasia L., Bajpai A., Soni K., "Effects of drip irrigation system for enhancing rice (Oryza sativa L.) yield under system of rice intensification management," Applied Ecology and Environmental Research, vol. 15, no. 4, pp. 487-495, 2017. DOI : 10.15666/aeer/1504_487495

[39] Luo L., "Breeding for water-saving and drought-resistance rice (WDR) in China," Journal of Experimental Botany, vol. 61, no. 13, pp. 3509-3517, 2010. https://doi.org/10.1093/jxb/erq185

[40] Fawibe O.O., Honda K., Taguchi Y., Park S., Isoda A., "Greenhouse gas emissions from rice field cultivation with drip irrigation and plastic film mulch," Nutrient Cycling in Agroecosystems, vol. 113, pp. 51-62, 2019. https://doi.org/10.1007/s10705-018-9961-3 